\title{
CULTIVATION OF 3D DERMAL TISSUE BY APPLICATION OF AUTOLOGOUS MATRIX
}

\author{
Ėriks Jakobsons ${ }^{1}$, Kristaps Ėrglis ${ }^{1}$, Anna Ramata-Stunda ${ }^{1}$, llze Blāke ${ }^{1}$, Liene Patetko ${ }^{1}$, \\ Simona Tìcmane ${ }^{1}$, Beatrise Lūcija Rupaine ${ }^{1}$, Mārtiňš Ërglis ${ }^{1}$, Māra Ërgle ${ }^{1}$, Eva Strīḳe ${ }^{2}$, \\ Uldis Strazdins ${ }^{2}$, Silvesters Rubīns ${ }^{3}$, Andris Rubinss ${ }^{3}$, and Andrejs Erglis ${ }^{2, \#}$ \\ ${ }^{1}$ Cell Transplantation Centre, Pauls Stradiṇš Clinical University Hospital, 13 Pilsoṇu Str., Rĩga, LV-1002, LATVIA \\ ${ }^{2}$ Latvian Centre of Cardiology, Pauls Stradiṇš Clinical University Hospital, 13 Pilsoṇu Str., Rīga, LV-1002, LATVIA \\ ${ }^{3}$ Faculty of Medicine, University of Latvia, 3 Jelgavas Str., Rīga, LV-1004, LATVIA \\ \# Corresponding author, a.a.erglis@stradini.Iv
}

Contributed by Andrejs Ërglis

\begin{abstract}
The most common reasons for major skin loss are thermal trauma - burns and scalds that can result in rapid, extensive, deep wounds as well as chronic non-healing wounds. Treatment using common techniques is poor and depending on the trauma level can result in death. There is a substantial need for skin integrity restoration. The main goal of this study was to develop an autologous 3D skin model that could eventually be translated into clinical applications. The study examined a variety of factors - extracellular matrix components, cell count, culture medium modification and role of structurally and functionally high-quality 3D skin dermis layer tissue culture production. The results of this study are an essential prerequisite to standardise the use of both clinical, as well as in vitro test systems. Dermal cell lines applied in the study were isolated form patient biopsies obtained at Pauls Stradinnš Clinical University Hospital. Blood plasma type AB was used for fibrin matrix formation. As catalysts, $\mathrm{CaCl}_{2}$ or calcium gluconate, and tranexamic acid were applied. 3D tissue functionality was assessed by evaluation of gene expression and changes in growth factor secretion. Fibrin matrix formulations with $1 \%$ and $1.5 \% \mathrm{CaCl}_{2}$ and $5 \mathrm{mg}$, $7 \mathrm{mg}$ and $10 \mathrm{mg}$ tranexamic acid concentration were tested. Better matrix properties were observed with higher concentration of $\mathrm{CaCl}_{2}$ and tranexamic acid. Differences in levels of collagen gene expression and growth factor secretion were observed. Changes in levels of fibroblast growth factor and gene expression were observed in fibrin matrix samples and the surface-cultivated cell culture monolayer, but structural protein synthesis was not detected.
\end{abstract}

Key words: autologous skin model, in vitro bioengineering, 3D skin cultivation.

\section{INTRODUCTION}

Tissue engineering is a multidisciplinary area of research, which aims to regenerate damaged tissues and organs in the human body. The general principle is to isolate cells from a patient who requires a transplant and subsequent culturing of the cells on a suitable support to produce the replacement tissue. On the one hand, it is necessary to find a suitable support on which cells can adhere and form stratified structures. On the other hand, the conditions allowing cells to proliferate and differentiate into various types of tissues must be understood and reproduced. At present, there are various materials used as support in the treatment of ulcers and burns (Negri et al., 2009).
Full-thickness skin defects caused by burns, soft tissue trauma and diseases leading to skin necrosis represent important clinical problems that are far from being solved. The main challenges are: 1) donor site shortage for autologous skin transplantation when the defect exceeds $50-60 \%$ of the total body surface area (a typical clinical example is a massive deep burn), and 2) most conventional skin grafting techniques to provide autologous defect coverage are based on transplanting split-thickness skin (Bottcher-Haberzeth et al., 2010).

The main goals of skin tissue engineering are healing and complete simulation of physiological skin, with close to native mechanical qualities, and lack of recipient toxicity or 
immune rejection (Boyce et al., 2001). In addition, the restoration of skin anatomy needs to go beyond rehabilitation of structural architecture and needs to include skin pigmentation, nerve, vascular plexus, and adnexa reinstitution. The design of artificial skin substitutes also needs to consider the genotype of the transplanted skin cells, the biocompatibility of materials applied and the complexity of fabrication (Boyce et al., 1996). The restoration of an intact barrier and prevention of sepsis are crucial in skin regeneration treatment, particularly in cases of large burns. Another important goal is the initiation of healing processes in the case of chronic wounds. The basic aspects for the design of artificial skin need consideration of physicochemical, biochemical and mechanical features (Yannas and Burke, 1980). Besides the issues mentioned above, an artificial skin transplant should control fluid regulation, avoid infection, promote contracture and scarification.

There are multiple potential approaches to improving skin regeneration. These include the choice of the type of cells, their source and cell processing during fabrication of the skin transplant. Future research should focus on how to decrease the risks of disease transmission in patients receiving artificial skin grafts. Additional research on the molecular basis of scar wound healing and simulation of scarless healing will continue to contribute to skin graft fabrication strategies (Bottcher-Haberzeth et al., 2010).

The aim of this study was to evaluate properties of autologous fibrin-based cell cultivation matrix.

\section{MATERIALS AND METHODS}

Cell lines. The cell lines D03 and D04 used in this study were extracted from patient biopsies obtained at Pauls Stradiňš Clinical University Hospital. Biopsies were collected from post-operative material, average sample size - 0.5-2 $\mathrm{cm}^{2}$. The study utilised the passage p0-9. Human cell lines were obtained in accordance with Latvian legislation and the Helsinki Declaration.

Fibrin matrix preparation. Fibrin matrix formation was performed according to the protocol of Negri et al. (2009). $\mathrm{CaCl}_{2}$ or calcium gluconate was used as a catalyst and tranexamic acid was used as an anti-fibrinolytics agent. The $\mathrm{AB}$ type plasma used for matrix formation was received from Pauls Stradiņš Clinical University Hospital blood preparation department.

Cell cultivation in 3D fibrin matrix. Dermal cell lines D03 and D04 were cultured in fibrin matrix. Matrix formulations containing $\mathrm{CaCl}_{2}(1 \%$ and $1.5 \%)$ and tranexamic acid (5 mg, $7 \mathrm{mg}, 10 \mathrm{mg}$ ) were tested. Samples were differentially dyed by two methods: 1) hematoxylin and eosin (H\&E) and 2) Masson's trichrome (TR) stain method.

Analysis of gene expression. Samples of cells from cultures were collected at days 7 and 21. RNA was isolated and cDNA was used for qPCR assay.
Changes in gene CollA1, MMP-1, FGF2, FGF7, EGF, FGFR1 expression were evaluated against quantity of PGK1 mRNA.

Changes in gene expression were compared between 3D matrix culture samples and the cell lines cultured on artificial surface.

In vivo skin gene expression was compared to in vitro cultured samples. RNA from skin samples was isolated and CollA1, FGF2 and FGF7 gene expression of dermis was quantified against PGK1 mRNA volume.

Analysis of growth factor synthesis dynamics. Growth factor analysis was carried out by ELISA assay, protein FGF2 and FGF7 levels were detected in 3D fibrin matrix culture media supernatant as well as on the surface of cultured cell culture media supernatants at days 7 and 21. The S10 culture medium supernatant from samples with a fibrin matrix without cells was used as a control.

\section{RESULTS}

Cell cultivation in 3d fibrin matrix. Dermal fibroblast cell lines obtained from two skin biopsies were cultured in fibrin matrix. Matrix formulations containing $\mathrm{CaCl}_{2}(1 \%$ and $1.5 \%)$ and tranexamic acid (5 mg, $7 \mathrm{mg}, 10 \mathrm{mg}$ ) concentration were applied. All combinations of components of matrix resulted in full polymerisation and cell culturing was successfully carried out. Cells cultured in a monolayer on plastic surfaces and 3D fibrin matrix (Fig. 1) showed differences in cell morphology. Both cell lines had uniform cell distribution in the matrix, forming a multilayer structure. After seven days of culturing, both cell lines show fibroblasts with characteristic spindle and star-shaped cell morphology for all matrix cells (Fig. 2, A, B), but after culturing cells for 21 days, cell morphology changed - the cells along the top edge of the matrix had a cubic shape that resembled epithelial layer cells (Fig. 2, C, D).

Samples were dyed by hematoxylin/eosin and Masson's trichrome method. Eosin and hematoxylin stain dyed samples showed the above changes in cell morphology at seven and 21 days. A change in the colour of Masson's trichrome stain was observed in samples from cell line D04 after cultivation for 21 days in fibrin matrix with $1.5 \% \mathrm{CaCl}_{2}$, and 10 $\mathrm{mg}$ tranexamic acid. A blue tint indicated possible presence of collagen in the extracellular matrix, but it is impossible to determine the fibre composition using a single differen-

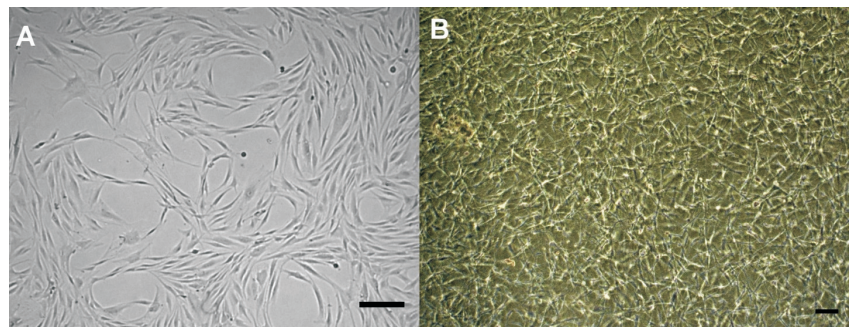

Fig. 1. Cell line D04 morphology cultivated on surface (A) or in 3D fibrin matrix (B). Scale corresponds to $100 \mu \mathrm{m}$ 


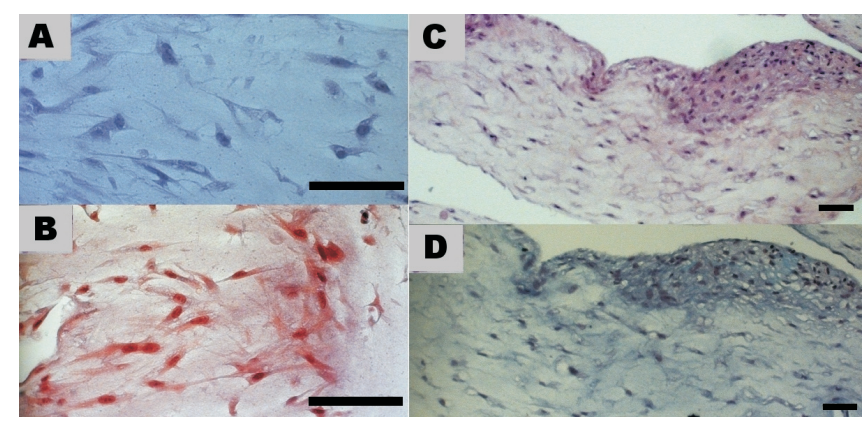

Fig. 2. Dermal cells cultivated in 3D fibrin matrix. A, day 7, cell line D03, H\&E; B, day 7, cell line D03, TR; C, day 21, cell line D04, E\&H; D, day21, cell line D04, TR. Scale corresponds to $100 \mu \mathrm{m}$.

tial staining method. In the D03 cell line samples this difference was not observed.

Comparison of matrix formulations shows that $\mathrm{CaCl}_{2}$ and tranexamic acid concentrations affected both matrix physical properties like cell proliferation and availability of testing. Cell proliferation takes place at a higher $\mathrm{CaCl}_{2}$ and tranexamic acid concentration, because at lower component concentrations matrix consistency is too liquid; and by influence of gravity most of cells are relocated towards matrix bottom layers. For this reason, $1.5 \% \mathrm{CaCl}_{2}, 7$ and $10 \mathrm{mg}$ tranexamic acid concentrations were used for further matrix formulations.

Analysis of gene expression. Gene expression was evaluated in 3D and 2D cultured cells. Samples of cells were collected at days 7 and 21. Changes in gene CollAl, MMP-1, $F G F 2, F G F 7, E G F, F G F R 1$ expression were evaluated against quantity of PGK1 mRNA. No changes were found in gene $M M P-1, E G F$ and $F G F R 1$ expression, and therefore testing of expression of these genes was excluded from further analysis.

Differences in gene expression were observed between cell lines for genes CollA1, FGF2 and FGF7 (see Figs. 3 and 4).

CollAl gene expression increased after seven days compared to 2D cultured cells, which was observed only in cell line D04 at $7 \mathrm{mg}$ tranexamic acid concentration. After 21 days of cultivation changes had occurred in D4 cell line at both tranexamic acid concentrations. In the cell D03 line at $7 \mathrm{mg}$ tranexamic acid concentration, CollAl gene expression was five times higher than in the control. At day 7 , $F G F 2$ gene expression had increased by ten and twenty times in samples with the $7 \mathrm{mg}$ and $10 \mathrm{mg}$ tranexamic acid concentration, respectively. Cell line D04 gene expression level was lower than the surface cultured cells at day 7 . However, at day 21, the cell line D3 FGF2 gene expression had decreased, while the D04 cell line at $10 \mathrm{mg}$ tranexamic acid concentration had a tenfold increase in the expression of this gene. Changes of $F G F 7$ gene expression were similar to that for the $F G F 2$ gene: at day $7, F G F 7$ expression had significantly increased in cell line D03 in both tranexamic acid concentrations and decreased expression in cell line D4, but on day 21 , gene expression had decreased in
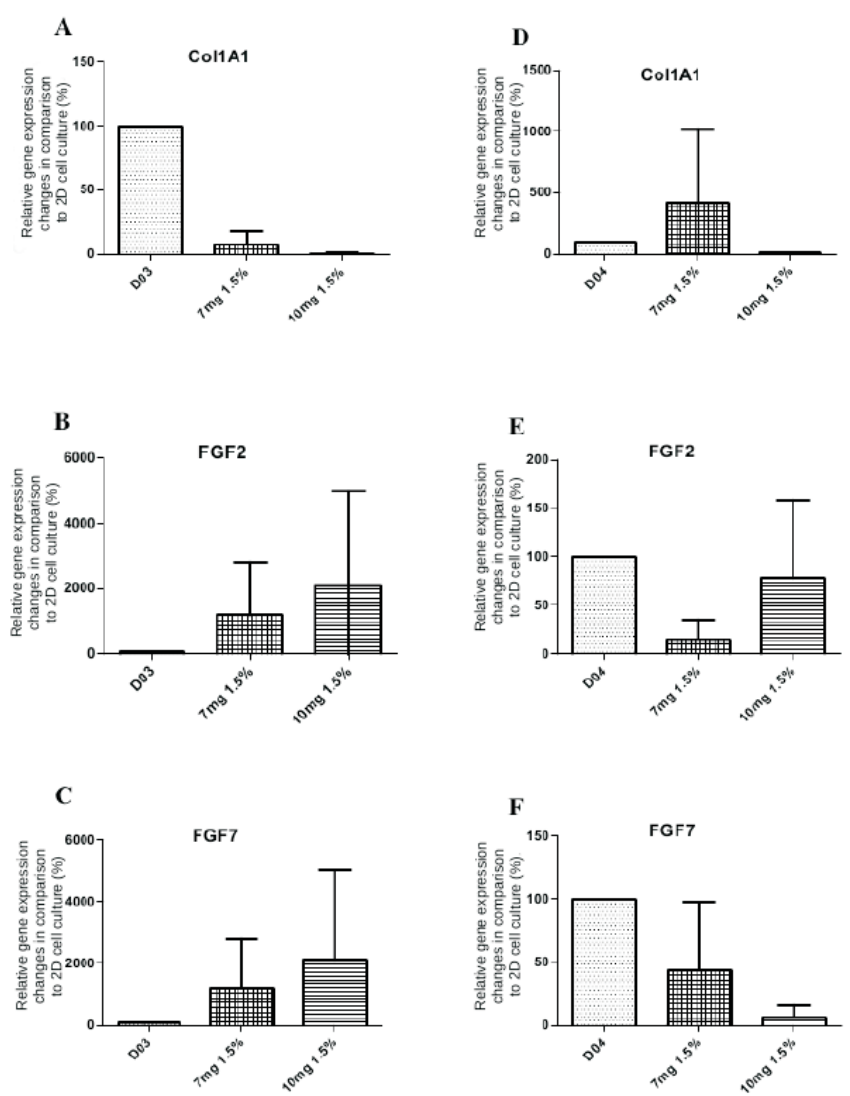

Fig. 3. Relative gene expression changes between cultivating cells for 7 days in 3D fibrin matrix with different tranexamic acid concentration and 2D. A, B and $\mathbf{C}-$ cell line D03; D, E and F - cell line D04.
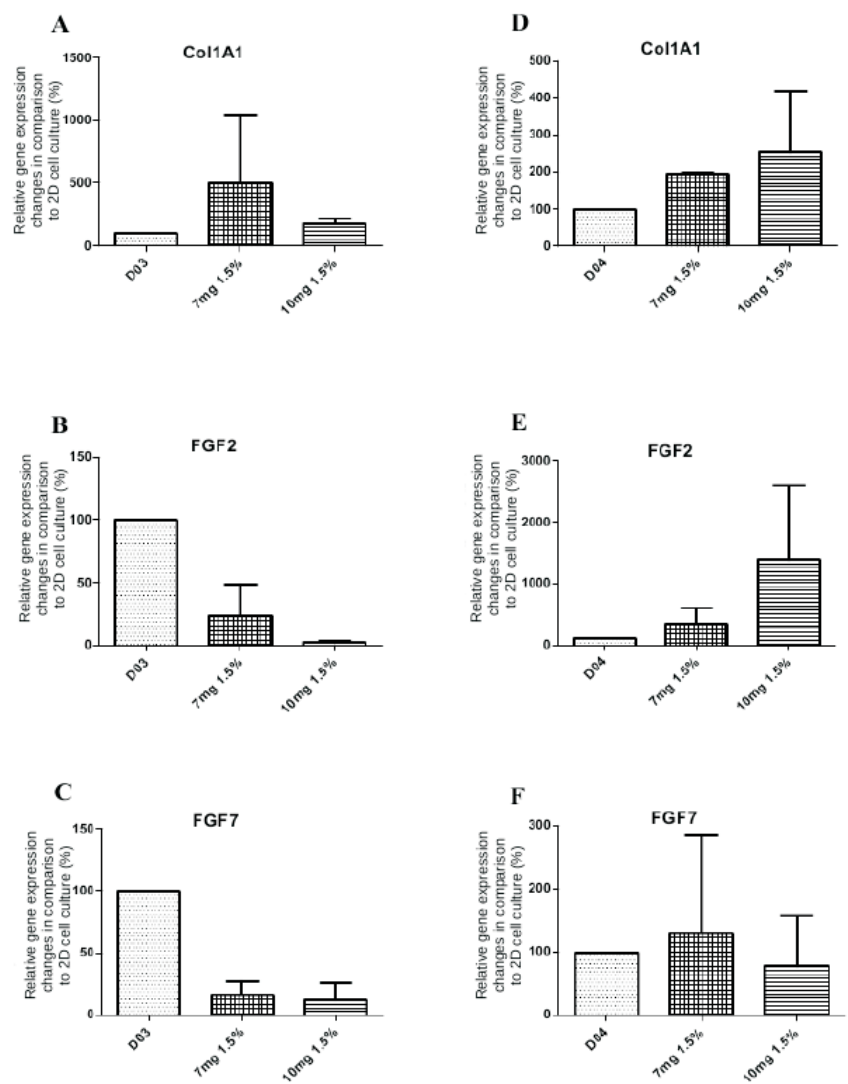

Fig. 4. Relative gene expression of cultivating cells at 21 days in 3D fibrin matrix with different tranexamic acid concentration and 2D. A, B and C cell line D03; D, E and F - cell line D04. 
Table 1. Gene expression of cells cultivated in 3D fibrin matrix in comparison to 2D cultivated cells and dermis. 1, cell line; 2, cultivation time; 3 , tranexamic acid concentration

\begin{tabular}{|c|c|c|c|c|c|c|}
\hline 1 & 2 & 3 & & CollA1 & $F G F 2$ & $F G F 7$ \\
\hline \multirow{8}{*}{ D03 } & \multirow[t]{4}{*}{ 7days } & \multirow{2}{*}{$7 \mathrm{mg}$} & compared to $2 \mathrm{D}$ & $\downarrow$ & $\uparrow 10 \mathrm{x}$ & $\uparrow 10 \mathrm{x}$ \\
\hline & & & compared to dermis & $\downarrow$ & $\rightarrow$ & $\uparrow 10 \mathrm{x}$ \\
\hline & & \multirow[t]{2}{*}{$10 \mathrm{mg}$} & compared to $2 \mathrm{D}$ & $\downarrow$ & $\uparrow 20 x$ & $\uparrow 20 x$ \\
\hline & & & compared to dermis & $\downarrow$ & $\uparrow 5000 \mathrm{x}$ & $\uparrow 2000 \mathrm{x}$ \\
\hline & \multirow[t]{4}{*}{ 21days } & \multirow[t]{2}{*}{$7 \mathrm{mg}$} & compared to $2 \mathrm{D}$ & $\uparrow$ & $\downarrow$ & $\downarrow$ \\
\hline & & & compared to dermis & $\downarrow$ & $\uparrow 3000 \mathrm{x}$ & $\uparrow 2000 \mathrm{x}$ \\
\hline & & \multirow[t]{2}{*}{$10 \mathrm{mg}$} & compared to $2 \mathrm{D}$ & $\uparrow$ & $\downarrow$ & $\downarrow$ \\
\hline & & & compared to dermis & $\downarrow$ & $\uparrow 30 \mathrm{x}$ & $\uparrow 10 \mathrm{x}$ \\
\hline \multirow[t]{8}{*}{ D04 } & \multirow[t]{4}{*}{ 7days } & \multirow[t]{2}{*}{$7 \mathrm{mg}$} & compared to $2 \mathrm{D}$ & $\uparrow$ & $\downarrow$ & $\downarrow$ \\
\hline & & & compared to dermis & $\uparrow 70 x$ & $\uparrow 700 \mathrm{x}$ & $\uparrow 400 \mathrm{x}$ \\
\hline & & \multirow[t]{2}{*}{$10 \mathrm{mg}$} & compared to $2 \mathrm{D}$ & $\downarrow$ & $\rightarrow$ & $\downarrow$ \\
\hline & & & compared to dermis & $\rightarrow$ & $\uparrow 20 x$ & $\uparrow 10 \mathrm{x}$ \\
\hline & \multirow[t]{4}{*}{ 21days } & \multirow[t]{2}{*}{$7 \mathrm{mg}$} & compared to $2 \mathrm{D}$ & $\uparrow$ & $\uparrow$ & $\uparrow$ \\
\hline & & & compared to dermis & $\downarrow$ & $\uparrow 20 x$ & $\uparrow 70 \mathrm{x}$ \\
\hline & & \multirow[t]{2}{*}{$10 \mathrm{mg}$} & compared to $2 \mathrm{D}$ & $\uparrow$ & $\uparrow 10 \mathrm{x}$ & $\rightarrow$ \\
\hline & & & compared to dermis & $\rightarrow$ & $\uparrow 70 \mathrm{x}$ & $\uparrow 20 \mathrm{x}$ \\
\hline
\end{tabular}

the D03 line, while for the D04 cell line at $7 \mathrm{mg}$ tranexamic acid concentration, FGF7 gene expression was slightly above the level of the control.

Dermis gene expression was also compared to that of cultured cell samples. CollA1, FGF2 and FGF7 gene expression were determined. Table 1 shows changes in gene expression of 3D matrix cultured cells in comparison with 2D cultured cells and derma.

At day 7, gene expression of CollA1 in cell line D03 was lower than in both 2D cultured cells and derma, FGF2 expression was generally high, and was even $50000 \%$ higher in cell line DO3 than in the derma sample at $10 \mathrm{mg}$ tranexamic acid concentration. Similarly, gene FGF7 expression was more than 200 000\% higher in cell line DO3 at $10 \mathrm{mg}$ tranexamic acid concentration than in normal dermis. At day 21, in cell line D3 CollAl expression was higher than in $2 \mathrm{D}$ cultured cells and lower than in in derma. FGF2 and FGF7 expression was lower cell line D3 than in 2D cultured cells, and more than $200000 \%$ higher than in derma at tranexamic acid concentration $7 \mathrm{mg}$.

On day 7, CollAl gene expression was higher in cell line D4 than in both 2D cultured cells and derma, but in FGF2 such increases are seen in comparison to the dermis of the sample with $7 \mathrm{mg}$ tranexamic acid concentration. GFF7 gene expression was lower in cell line D4 than in 2D cultured cells expression but $400000 \%$ higher than in dermis. On day 21, in cell line D4, CollA1 gene expression was slightly higher than in $2 \mathrm{D}$ cultured cells, but lower than in derma. FGF2 expression at both tranexamic acid concentrations was higher in in cell line D4 than in 2D cultured cells and derma by several hundred per cent, while FGF7 gene expression in cell line D4 was significantly higher by more
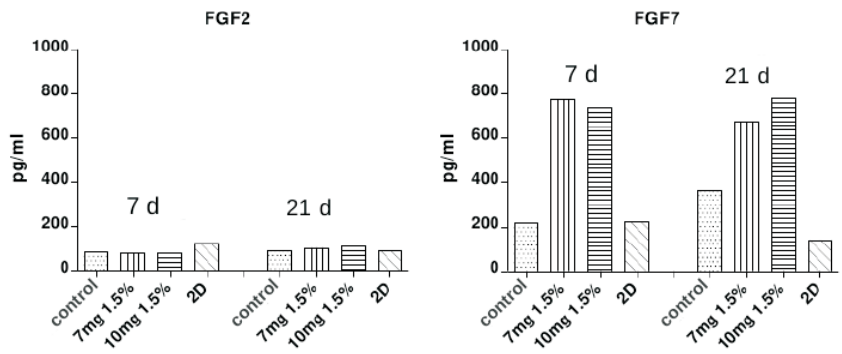

Fig. 5. FGF2 and FGF7 protein concentrations after 7 and 21 days of cultivating cell line D04 in 3D fibrin matrix with different tranexamic acid concentrations.

than $6000 \%$ and $2000 \%$ for derma at $7 \mathrm{mg}$ and $10 \mathrm{mg}$ tranexamic acid concentration, respectively.

Analysis of growth factor synthesis dynamics. ELISA assays were used to determine protein FGF2 and FGF7 levels in 3D fibrin matrix and on surface cultivated cell culture media supernatant days 7 and 21. FGF2 and FGF7 protein concentrations are shown in Figure 5.

None of the cell line samples showed significant secretion of FGF2 protein compared to the control samples and cultivated $2 \mathrm{D}$ cultures. Maximum FGF7 protein concentration of $774 \mathrm{pg} / \mathrm{ml}$ was reached on day 7 in samples with tranexamic acid concentration $7 \mathrm{mg}$, the level fell to $674 \mathrm{pg} / \mathrm{ml}$ on day 21. Such a trend is observed in samples with tranexamic acid concentration of $10 \mathrm{mg}$, but throughout the cultivation period, the protein concentration is higher than in the control. Control samples of polymerized fibrin matrix without cells showed the presence of FGF7 and FGF2 protein, indicating that plasma contains a certain level of growth factors.

\section{DISCUSSION}

This study showed that it is possible to create a 3D dermis cell culture model using easily available materials at low cost - plasma, $\mathrm{CaCl}_{2}$, tranexamic acid and saline. Compatibility of different fibrin matrix components was evaluated. In general, all variants of the experiment were successful, as plasma polymerised and 3D matrix was formed. Various publications describe methods of forming matrix using $\mathrm{CaCl}_{2}(1 \%$ and $1.5 \%)$ and tranexamic acid (5-10 mg) polymerisation (Negri et al., 2009). Minor differences were observed in the physical properties of the matrix; matrix structure was more liquid at lower concentrations of $\mathrm{CaCl}_{2}$ and tranexamic acid, where cells tended to sediment and physical properties of matrix did not allow to move it without breaking matrix layer. This could be caused by lack of tranexamic acid, which can lead to insufficient inhibition of plasminogen activation and occurrence of slight fibrinolytic activity. Higher $\mathrm{CaCl}_{2}$ and tranexamic acid concentrations of the matrix resulted in increase of stiffness and density.

Prolonged cell culturing (three weeks) resulted in changes of morphology of upper matrix layer cells, which began to resemble epithelial layer cells. It should be noted that dermal matrix was cultured covered with medium, so in this 
case the cell morphology changes could not be initiated by air/matrix surface exposition, which is the precondition for epidermal cell culture stratification (Bernstam et al., 1986). Histological dying with Masson's trichrome for cell line D04 at day 21 day for samples cultivated in matrix with $1.5 \% \mathrm{CaCl}_{2}$ and $10 \mathrm{mg}$ tranexamic acid showed potential collagen presence in matrix, indicating a possible late collagen synthesis initiation. Collagen deposition in extracellular matrix can be initiated at different cultivation times according to cell line specification. This might be related to a specific matrix shrinkage both in a vertical and a horizontal plane, which is a typical, but undesirable process. This phenomenon is caused by fibroblast differentiation into miofibroblasts, which normally takes place during wound healing. It ensures wound surface reduction and tightening of tissues without cell migration (Harrison and MacNeil, 2008).

Both the analysis of gene expression and secretion of growth factors showed differences between the cell lines, which indicates that a cell line choice for $3 \mathrm{D}$ tissue culture model design is essential. This must be taken into account for further optimisation and evaluation of the matrix component concentration and cultivation time effects on tissueculture functionality. Since the current results showed contrasting results, such as for $F G F 7$ gene expression in the tested cell lines, work should be continued, and gene expression and protein secretion should be assessed in vast number of different cell lines. There is a need for more detailed characterisation of cell cultures before the use for tissue culture model design — growth factor and structural protein gene expression profile characterisation should be firstly applied. Potential application of dermal/epidermal 3D cultures as model systems or as skin substitute transplants requires knowledge of critical control points for growth factor expression and secretion. For example, a skin substitute transplant will be ineffective if using cell line with low or insufficient secretion of growth factors needed for wound healing processes. Also, it is important to assess whether a too high expression level of a certain growth factor might result in adverse effects after tissue culture clinical application.

Overall, the data on gene expression showed that collagen synthesis is reduced and delayed, which is also consistent with the results obtained by histological cut staining, especially compared to the collagen I gene expression, which is observed in postoperative obtained dermis material. This should be not viewed negatively in the case of clinical application, as fibrin matrix provides surface cell adhesion, migration, proliferation and forms a sufficiently flexible, physical and functional structure that can benefit wound healing and skin integrity restoration. Collagen synthesis might be delayed due to migration and division of cells. But this do not benefit experimental tissue models that are used in a variety of tissue functionality studies where the presence of structural proteins is very important, because these models have to imitate the in vivo structures more accurately.
The data on fibroblast growth factor gene expression showed higher $F G F 2$ and $F G F 7$ gene expression during cell culturing in the matrix compared to the dermis obtained from postoperative material, but different results were observed compared to cells cultured in 2D. Such differences suggest changes in cell functional status by cultivating them in a different environment, shown by differences in growth factor secretion, gene expression and protein secretion by the ELISA analysis. Culture media supernatant was used for analysis, but as it is unknown if the growth factors are binding to matrix, so it is unclear if all secreted growth factors were presented in culture media.

Cell cultivation in fibrin matrix simulates skin as a structure, and in processes of regeneration and wound healing, and in proliferation phases of reconstruction. Increased fibroblast growth factor expression is characteristic for wound healing (Komi-Kuramochi et al., 2005). Fibroblast growth factors promote tissue repair in vivo and also promote and improve tissue engineering forming a skin model quality and functional state (Erdag and Morgan, 2004).

There is clear need to conduct further experiments on cultivation of fibrin matrix with existing and additional donor cell lines to obtain a sufficient data set related to patient specific factors that can influence gene and growth factor expression during cell cultivation (Pillet et al., 2017; Chung et al., 2016). Further studies should be addressed to evaluate advantages and disadvantages of cell culture, cell culturing in other types of matrix (biodegradable synthetic polymers and collagen matrix), and other growth factor gene expression profiles, such as VEGF, which is an important factor in angiogenesis and essential for the production of autologous skin transplant functionality (Benny et al., 2016).

\section{CONFLICT OF INTEREST}

The authors certify that they have no affiliations with or involvement in any organisation or entity with any financial interest, or non-financial interest in the subject matter or materials discussed in this manuscript.

\section{ACKNOWLEDGEMENTS}

This study was supported in part by Estonian-Latvian cross-border cooperation programme project DELMA (Development of Estonian-Latvian Medical Area) and by grant from corporation Sistēmu Inovācijas.

\section{REFERENCES}

Benny, P., Badowski, C., Lane, E. B., Raghunath, M. (2016). Improving 2D and $3 \mathrm{D}$ skin in vitro models using macromolecular crowding. J. Vis. Exp., doi: 103791/53642.

Bernstam, L. I., Vaughan, F. L., Bernstein, I. A. (1986). Keratinocytes grown at the air-liquid interface. In Vitro Cell Dev. Biol., 22, 695-705.

Bottcher-Haberzeth, S., Biedermann, T., Reichmann, E. (2010). Tissue engineering of skin. Burns, 36, 450-460. 
Boyce, S. T. (2001). Design principles for composition and performance of cultured skin substitutes. Burns, 27, 523-533.

Boyce, S. T. (1996). Cultured skin substitutes: Review. Tissue Eng., 2, 255-266.

Chung, E., Rybalko, V. Y., Hsieh, P. L., Leal, S. L., Samano, M. A., Willauer, A. N., Stowers, R. S., Natesan, S., Zamora, D. O., Christy, R. J., Suggs, L. J. (2016). Fibrin-based stem cell containing scaffold improves the dynamics of burn wound healing. Wound Repair Regen., 24 (5), 810-819.

Erdag, G., Morgan J. R. (2004). Allogeneic versus xenogeneic immune reaction to bioengineered skin grafts. Cell Transplant, 13 (6), 701-712.

Harrison, C. A., MacNeil, S. (2008). The mechanism of skin graft contraction: An update on current research and potential future therapies. Burns, 34, 153-163.

Received 28 January 2019

Accepted in the final form 23 September 2019
Komi-Kuramochi, A., Kawano, M., Oda, Y., Asada, M., Suzuki, M., Oki, J., Imamura, T. (2005). Expression of fibroblast growth factors and their receptors during full-thickness skin wound healing in young and aged mice. $J$ Endocrinol., 186 (2), 273-89.

Negri, S., Federici, G., Farinato, S.., Fila, C. (2009). Human plasma as a dermal scaffold for the generation of a completely autologous bioengineered skin. J. Clin. Rehab. Tissue Eng. Res., 13 (47), 9211-9216.

Pillet., F., Gibot, L., Madi, M., Rols, M. P., Dague. E. (2017). Importance of endogenous extracellular matrix in biomechanical properties of human skin model. Biofabrication, 9 (2), 025017.

Yannas, I. V., Burke, J. F. (1980). Design of an artificial skin. I. Basic design principles. J. Biomed. Mater. Res., 14, 65-81.

\section{DERMAS AUDU 3D KULTIVĒŠANA, IZMANTOJOT AUTOLOGU MATRIKSU}

Biežākais nopietnu ādas zudumu iemesls ir termālās traumas — apdegumi un apsaldējumi, kas ātri pārvēršas ekstensīvās un dziḷās brūcēs, tai skaitā hroniskās un nedzīstošās brūcēs. Šobrīd pieejamās terapijas iespējas ir ierobežotas un nesniedz nepieciešamo risinājumu. Tāpēc ir nepieciešami jauni risinājumi ādas integritātes atjaunošanai. Pētījuma galvenais mērḳis ir izveidot autologu 3D ādas modeli, kuru būtu iespējams pielietot jaunu medicīnas tehnolog̣iju izstrādē. Pētījuma gaitā tika novērtēta dažādu faktoru — ekstracelulārā matriksa komponenšu, šūnu skaita, kultivēšanas vides ietekmi uz strukturāli un funkcionāli kvalitatīva 3D dermas slāṇa izveidošanu. Pētījuma gaitā izmantotās dermas šūnu līnijas tika izdalītas no pacientu biopsijām, kas tika iegūtas Paula Stradiṇa Klīniskajā universitātes slimnīcā. Fibrīna matriksa veidošanai tika izmantota $\mathrm{AB}$ tipa asins plazma. Fibrīna matrikss tika izgatavots, kā katalizatoru izmantojot $\mathrm{CaCl}_{2}$ vai kalcija glukonātu un/vai traneksām skābi. 3D dermas slāņa funkcionalitāte tika novērtēta, salīdzinot gēnu ekspresijas un augšanas faktoru izdalīšanās izmaiņas. Pētījuma gaitā tika izgatavoti 3D dermas slāņa paraugi, matriksa veidošanai izmantojot $1 \%$ un $1.5 \% \mathrm{CaCl}_{2}$ un $5 \mathrm{mg}$, $7 \mathrm{mg}$ un $10 \mathrm{mg}$ traneksānskābes koncentrāciju. Labākas matriksa funkcionālās īpašības tika novērotas, izmantojot augstākās $\mathrm{CaCl}_{2}$ un traneksānskābes koncentrācijas. Tika novērotas izmaiṇas kolagēna gēnu ekspresijas un augšanas faktoru sekrēcijas līmenī. Salīdzinot fibrīna matriksa paraugus ar monoslānī audzētām šūnu kultūrām, tika novērota paaugstināta fibroblastu augšanas faktora sekrēcija un gēnu ekspresija, bet strukturālo proteīnu sintēze netika novērota. 